\title{
Video Digital Untuk Arkeologi
}

\section{Sofwan Noerwidi}

Keywords: public archaeology, audio-visual, media, practices, documentation, documentary

\section{How to Cite:}

Noerwidi, S. (2006). Video Digital Untuk Arkeologi. Berkala Arkeologi, 26(2), 13-26. https://doi.org/10.30883/jba.v26i2.931

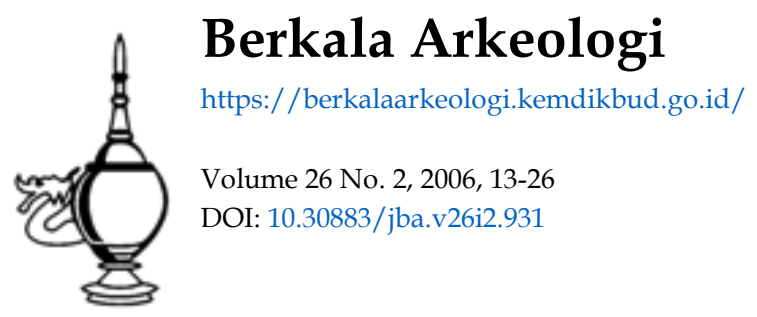

\section{(c) (†) (2)}

This work is licensed under a Creative Commons Attribution-NonCommercial-ShareAlike $\underline{4.0}$ International License. 


\title{
VIDEO DIGITAL UNTUK ARKEOLOGI
}

\author{
Sofwan Noerwidi
}

\begin{abstract}
Abstrak
Dokumen penelitian berupa audio-visual sebagai salah satu bentuk dokumentasi penelitian, sampai saat ini belum banyak mendapat perhatian yang serius. Padahal sumber-sumber tersebut merupakan bahan yang sangat potensial untuk mempublikasikan arkeologi kepada masyarakat luas. Tulisan ini secara khusus akan membahas dokumen audio-visual beserta keluarannya dalam bentuk video digital dokumenter kearkeologian. Pada instansi Balai Arkeologi Yogyakarta, bentuk publikasi semacam ini merupakan produk yang keluarannya diusahakan secara rutin pada setiap akhir penelitian serta pada peristiwa-peristiwa penting lainnya yang berkenaan dengan sumberdaya arkeologi.
\end{abstract}

\section{ARKEOLOGI PUBLIK}

Walaupun dalam undang-undang dinyatakan bahwa penguasaan sumberdaya arkeologi (benda cagar budaya dan situs) secara de yure dimiliki oleh negara, namun kenyataan dilapangan secara de facto tetap dimiliki oleh masyarakat. Di era global ini, ketika masyarakat telah memperoleh pencerahan dan sadar akan hak-haknya maka muncul tuntutan dengan apa yang dinamakan Public Archaeology. Arkeologi publik (Public Archaeology) merupakan laku arkeologi yang kiblatnya adalah arkeologi untuk masyarakat. Laku arkeologi untuk masyarakat didasari oleh pemikiran bahwa sumberdaya arkeologi pada hakekatnya adalah milik masyarakat luas, sehingga segala sesuatu yang terjadi pada sumberdaya tersebut harus sepengetahuan masyarakat (Tanudirjo, 2003:xvi). 
Dalam kaitannya dengan laku arkeologi untuk masyarakat, para arkeolog harus bertindak sebagai steward. Dalam kedudukan ini, arkeolog harus menyadari bahwa meraka hanya sebagai penjaga dan pengelola sesuatu yang sebenarnya bukan miliknya sendiri (Tanudirjo, 2003:xvii). Dalam hal ini, arkeolog tidak dapat bertindak semena-mena karena aset yang dikelola tersebut bukan miliknya, dan sebaliknya arkeolog harus mau mendengarkan aspirasi pemilik sumberdaya arkeologi yang bersangkutan. Oleh karena itu, arkeolog secara profesional harus bertanggungjawab atas sumberdaya arkeologi yang telah mereka "eksploitasi", baik untuk kegiatan penelitian (menambah kredit point bagi peneliti) maupun pemanfaatan-pengembangan (mendatangkan uang bagi investor).

Aspek penting lainnya dalam laku arkeologi untuk masyarakat adalah proses redistribusi hasil eksploitasi sumberdaya arkeologi. Jika suatu sumberdaya arkeologi telah dieksploitasi, maka idealnya adalah agar hasilnya juga didistribusikan kembali kepada masyarakat luas, khususnya masyarakat lokal yang secara de facto menguasai sumberdaya arkeologi yang bersangkutan. Sehingga para steward (arkeolog) dihargai oleh masyarakat, dan tidak dicela dan dicap sebagai penguasa yang semena-mena. Dalam kaitannya dengan penelitian arkeologi, proses redistribusi sumberdaya arkeologi salah satunya mencakup informasi hasil kegiatan penelitian dan intepretasi yang dihasilkan sumberdaya arkeologi tersebut.

Seringkali masyarakat bertanya, mengapa tanahnya diobrak-abrik untuk kegiatan arkeologi? Mengapa arkeolog menghambur-hamburkan uang negara untuk penelitian arkeologi? Mana hasilnya? Maka sudah selayaknya jika masyarakat mendapatkan jawaban atas berbagai pertanyaan tersebut. Apalagi sampai saat ini penelitian dan pengelolaan arkeologi Indonesia masih berkiblat pada laku arkeologi negara (Archaeology in the Service of the State) yang hampir seluruh kegiatannya dibiayai oleh negara, sedangkan salah satu pendapatan utama negara adalah pajak yang ditarik dari rakyat. Oleh karena itu maka arkeolog secara profesional memiliki tanggungjawab untuk menginformasikan hasil kegiatannya bukan hanya kepada kalangan akademik, tetapi juga kepada masyarakat luas (McGimsey dan Davis, 1977:78). 
Beberapa keuntungan yang dapat diperoleh dari publikasi hasil kegiatan arkeologi kepada masyarakat luas antara lain adalah: memberikan informasi yang valid kepada masyarakat mengenai sumberdaya arkeologi yang ada di sekitar mereka, meningkatkan apresiasi dan respon positif serta kepedulian publik terhadap penelitian, pelestarian, pemanfaatan dan pengembangan sumberdaya arkeologi, serta dapat befungsi sebagai strategi prefentif untuk mencegah perusakan terhadap sumberdaya arkeologi (Sharer dan Ashmore, 2003: 618). Sehingga disadari bahwa penyebarluasan informasi hasil kegiatan arkeologi merupakan bagian yang tidak dapat dipisahkan dalam sebuah alur penelitian arkeologi.

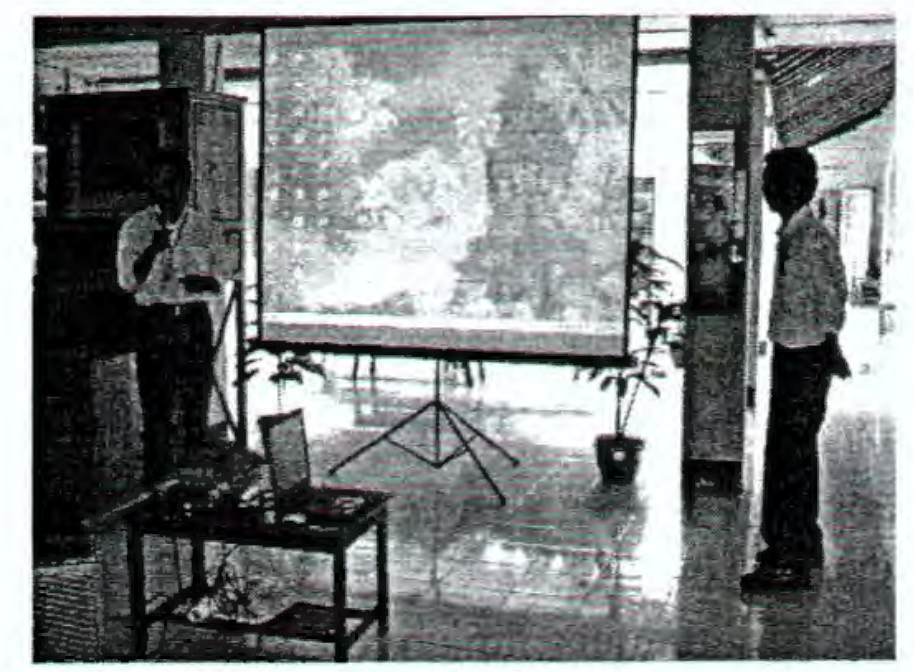

Pemutaran Film Pengetahuan Kearkeologian, Salah Satu Bentuk Pemasyarakatan Hasil Penelitian

\section{DOKUMENTASI PENELITIAN}

Sehubungan dengan publikasi hasil kegiatan arkeologi, maka produk yang dipublikasikan kepada masyarakat luas adalah dokumentasi penelitian. Oleh karena itu, pendokumentasian data merupakan salah satu rangkaian penting dalam kegiatan penelitian arkeologi. Tanpa perekaman data (dokumentasi penelitian) yang baik dan lengkap, maka penelitian arkeologi (terutama yang dilakukan dengan ekskavasi) sama halnya dengan perusakan terhadap sumberdaya arkeologi. Dokumentasi penelitian merupakan data tingkat kedua (data sekunder) yang mungkin akan menjadi satu-satunya sumber bagi peneliti berikutnya, karena banyak aspek dari data pertama (data primer) telah rusak sebagai konsekuensi dari proses ekskavasi. 
Bentuk dokumentasi penelitian dapat dibagi menjadi (Sektiadi, 2000):

1. Dokumen verbal (tulis): catatan harian, deskripsi, label, tabel, rekapitulasi, dan lainnya

2. Dokumen piktorial (gambar): gambar (berupa peta, denah, potongan, profil, elevasi, perspektif, dan isonometri/aksonometri) dan foto

3. Dokumen audio-visual, berupa perekaman yang dilakukan dengan menggunakan citra bergerak dan suara.

Sedangkan berbagai macam bentuk publikasi yang sampai saat ini telah dilakukan oleh Puslitbang Arkeologi Nasional dan Balai Arkeologi pada umumnya adalah (Riyanto, 2003:135):

1. Berbagai bentuk penerbitan baik ilmiah, semi popular, maupun popular

2. Media masa yang meliputi media elektronik (televisi dan radio) serta media cetak (koran dan majalah)

3. Publikasi digital seperti jaringan (LAN, Web Site dan Internet), media pandangdengar (audio-visual), multi media, CD-Interaktif, CD-Slideshow dan Video Digital (VCD, SVCD, DVD)

4. Pemasyarakatan langsung dengan mengadakan kegiatan pameran, ceramah, sarasehan, penyuluhan dan lainnya

5. Kegiatan internal seperti pertemuan ilmiah dan perpustakaan

Salah satu dari berbagai aspek dokumentasi dan publikasi hasil kegiatan arkeologi tersebut di atas yang secara khusus akan dibahas dalam tulisan ini adalah dokumentasi penelitian berupa audio-visual beserta keluarannya dalam bentuk video digital dokumenter kearkeologian. Pada instansi Balai Arkeologi Yogyakarta, bentuk publikasi semacam ini merupakan produk yang keluarannya diusahakan secara rutin pada setiap akhir penelitian serta pada peristiwa-peristiwa penting lainnya yang berkenaan dengan sumberdaya arkeologi.

\section{EVALUASI}

Dokumen audio-visual sebagai salah satu bentuk dokumentasi penelitian, sampai saat ini belum banyak mendapat perhatian yang serius. Padahal sumber-sumber tersebut merupakan bahan yang sangat potensial untuk mempublikasikan arkeologi 
kepada masyarakat luas. Beberapa evaluasi dapat dilakukan pada kegiatan dokumentasi audio-visual yang meliputi:

1. Kegiatan Pra-lapangan: Biasanya tema dan topik, skenario serta konsep Point of Interest (POI) belum digarap dengan maksimal

2. Kegiatan Lapangan: kendala yang dihadapi pada saat kegiatan eksekusi di lapangan antara lain adalah:

a. Keterbatasan kemampuan sumberdaya manusia, sehingga mempengaruhi teknik dan hasil eksekusi

b. Keterbatasan peralatan yang mampu menghasilkan dokumentasi audio-visual berkualitas

3. Kegiatan Pasca-Lapangan: kendala yang dihadapi pada saat kegiatan pascalapangan (kegiatan studio) antara lain adalah:

a. Dokumentasi audio-visual hasil kegiatan arkeologi yang berbentuk hardware (kaset VHS, Hi-8 dan Mini DV) yang disimpan di dalam gudang dokumentasi, hanya dibiarkan bertumpuk, kotor, berdebu, lembab, menjamur, bahkan dirusak oleh serangga

b. Masih minimnya tindaklanjut pada hardware dokumentasi audio-visual untuk dikembangkan menjadi salah satu produk hasil penelitian selain laporan verbal dan piktorial

Berdasarkan beberapa permasalahan di atas maka perlu dipikirkan jalan keluar untuk mengoptimalkan produk dari dokumen audio-visual yang berlimpah tersebut. Beberapa tahun belakangan ini arkeolog selalu bergelut untuk mempelajari strategi mempublikasikan arkeologi kepada masyarakat luas. Sudah tidak diragukan lagi bahwa kebanyakan arkeolog dapat menjelaskan masa lampau, namun dapatkah mereka juga membuat hal tersebut menarik dan relevan sehingga diminati oleh masyarakat luas? (Lerner dan Hoffman, 19:231). Salah satu strategi untuk menjawab pertanyaan tersebut adalah publikasi melalui media audio-visual dengan keluarannya dalam bentuk video digital dokumenter kearkeologian (film dokumenter arkeologi).

Berbagai film-film ilmiah arkeologi, baik yang fiksi maupun non-fiksi telah banyak diproduksi sehingga mampu mempopulerkan ilmu arkeologi pada masyarakat luas. 
Sebagai contoh adalah film ilmiah fiksi yang telah menginspirasikan banyak anakanak sehingga tertarik untuk menggeluti bidang arkeologi, paleontologi dan antropologi adalah film yang mengisahkan petualangan Indiana Jones (arkeologi) dan Robinson Crussoe (etnografi), serta Jurassic Park (paleontologi). Sedangkan contoh film ilmiah non-fiksi yang bersifat dokumenter adalah film-film produksi National Geographic dan Discovery Chanel.

\section{PENGEMBANGAN}

Sudah disepakati dalam pemaparan di atas bahwa salah satu strategi untuk mempublikasikan arkeologi kepada masyarakat luas adalah melalui media audiovisual dengan keluarannya dalam bentuk video digital dokumenter kearkeologian (film dokumenter arkeologi). Beberapa alternatif jalan keluar bagi berbagai permasalahan yang menyangkut produksi film dokumenter kearkeologian akan dibahas di bawah ini, antara lain adalah:

\section{A. Tema dan Topik}

Kesulitan pertama yang sering kali dihadapi adalah menemukan tema untuk film dokumenter yang akan diproduksi. Ide cerita terkadang datang dengan sendirinya, hanya seringkali ada kesulitan untuk menuangkannya. Hal tersebut dapat disebabkan oleh karena kurangnya referensi dalam wawasan kita atau malah sebalikya terlalu penuhnya referensi yang ada sehingga membingunkan otak kita karena keseluruhannya dianggap penting dan harus dituangkan. Untuk itu maka berawal dari masing-masing diri kita untuk menambah wawasan jika dirasa kurang dan berpikir selektif(spesifik) bagi yang merasa terlalu dijejali informasi.

Tema film dokumenter kearkeologian salah satunya dapat diperoleh dengan cara mengamati alur perjalanan sumberdaya arkeologi pada masing-masing konteks sistemnya, yaitu:

1. Living System, merupakan sistem tempat sumberdaya akeologi masih berada dalam konteks budaya masyarakat pendukungnya. Pembuatan film dokumenter pada konteks ini bertujuan untuk memahami proses buat, fungsi dan makna sumberdaya akeologi berdasarkan konsep masyarakat pendukungnya, sampai akhirnya tidak digunakan lagi atau hilang dan terdeposisi di suatu tempat. 
Pembuatan film dokumenter ini lebih bersifat etnografis dengan obyek budaya materi yang masih berada dalam konteks budaya masyarakat pendukungnya.

2. Taphonomic System, merupakan sistem yang belangsung sejak suatu obyek terdoposisi sampai ditemukan kembali oleh arkeolog. Pembuatan film dokumenter pada konteks ini bertujuan untuk memahami faktor-faktor budaya (Cultural Transform) maupun alam (Natural transform) yang berpengaruh terhadap berbagai macam proses pembentukan data arkeologi yang beragam dengan karakteristik yang berbeda.

3. Retrieval System, merupakan upaya untuk menemukan kembali benda-benda arkeologis. Pembuatan film dokumenter pada konteks ini bertujuan untuk menggambarkan proses penemuan sumberdaya arkeologi secara ilmiah dengan metode arkeologi, selain itu juga bertujuan untuk merekonstruksi kembali kehidupan manusia yang melatarbelakangi keberadaannya (living system). Dengan demikian film ini dapat berguna untuk menghubungkan antara kehidupan yang pernah berlangsung pada masa lampau dengan berbagai kepentingan kita di masa sekarang dan yang akan datang.

4. Conservation System, merupakan usaha untuk melestarikan sumberdaya arkeologi dari ancaman perusakan, baik oleh faktor manusia maupun alam. Pembuatan film dokumenter ini bertujuan untuk menggambarkan usaha pelestarian, pemanfaatan, dan pengembangan sumberdaya arkeologi dengan cara perlindungan legislasi, restorasi, konservasi, maupun pengembangan dan penyajian menjadi taman arkeologi (Archaeological Park).

Tema film dokumenter arkeologijuga dapat diperoleh dengan mengkombinasikan contoh-contoh di atas. Selain beberapa contoh diatas, tema film dokumenter juga dapat berasal dari koran, tabloid, majalah dan berbagai terbitan media masa yang memuat isu-isu relevan dan up to date, inspirasi dan modifikasi dari film-film yang telah diproduksi, maupun dari trend yang sedang berkembang di kalangan tiap segmen masyarakat yang berbeda (Set dan Sidharta, 2003:14-23).

\section{B. Skenario}

Skenario adalah sebuah cerita yang telah ditata dan dipersiapkan menjadi naskah jadi yang siap diproduksi. Penataan dilakukan untuk membuat struktur cerita dengan 
format tertentu. Dalam struktur terdiri dari beberapa hal antara lain adalah (Set dan Sidharta, 2003:24-26):

1. Inti cerita atau premise yang akan menjadi dasar dalam membentuk plot cerita

2. Plot adalah jalan cerita atau alur cerita dari awal, tengah dan akhir. Sebelum menulis naskah, sebaiknya plot cerita harus sudah diketahui terlebih dahulu, sehingga diketahui arah jalan ceritanya dan tidak kehilangan ide dalam menyambung cerita.

3. Struktur cerita yang dibagi ke dalam beberapa babak. Pembagian ini harus dapat diatur secara rapi untuk memudahkan eksekusi di lapangan.

\section{Point of Interest}

Pada prinsipnya, Point of Interest (POI) adalah bagian-bagian inti cerita yang digunakan untuk membangun film berdasarkan skenario yang telah disusun menjadi sebuah satu kesatuan runtutan cerita. Untuk pembuatan film dokumenter arkeologi, POI dapat terdiri dari beberapa macam, misalnya (Riyanto, $\mathrm{tt}$ ):

a. Sumberdaya arkeologi, terdiri dari: monumen, artefak, ekofak, situs, konteks, persebaran, dan aspek lainnya

b. Lingkungan, terdiri dari: lingkungan alam, kondisi sosial, budaya, ekonomi, dan kondisi masyarakat lainnya

c. Interaksi publik dengan obyek / benda cagar budaya dan situs, terdiri dari: apresiasi, aktivitas, perilaku, tanggapan, harapan

d. Narasumber, terdiri dari: masyarakat, tokoh, ahli, pejabat, dan berbagai stakeholder lainnya yang berhubungan dengan kegiatan penelitian serta konservasi sumberdaya arkeologi yang bersangkutan

e. POI yang terekam tiba-tiba, terdiri dari: snapshot dan candidshot

\section{Peningkatan Skill Sumberdaya Manusia}

Guna meningkatkan kemampuan SDM untuk memproduksi film dokumenter arkeologi, maka pada program kerja Pokja. Dokumentasi dan Informatika, Balai Arkeologi Yogyakarta tahun anggaran 2006 mengadakan beberapa pelatihan dasar, antara lain adalah:

1. Pelatihan video editing

2. Pelatihan animasi

3. Pelatihan GIS 
Pelatihan video editing merupakan pelatihan pokok yang berguna untuk menghasilkan SDM yang mampu mengedit data-data digital audio-visual. Pelatihan animasi berguna untuk mendukung pelatihan video editing, karena produk animasi sangat berguna untuk menghasilkan film dokumenter yang atraktif dan tidak membosankan tănpa mengurangi nilai akademisnya. Sedangkan pelatihan GIS selain berguna untuk menghasilkan SDM yang berkualitas dalam bidang Kartografi, produknyajuga berguna untuk menghasilkan tampilan film dokumenter yang valid, terutama yang berhubungan dengan pemetaan.

\section{E. Peralatan}

Beberapa peralatan dan perlengkapan standar minimal yang diperlukan untuk memproduksi sebuah film dokumenter arkeologi dapat dibedakan berdasarkan jenis kegiatannya, antara lain yaitu:

1. Kegiatan Eksekusi: peta, GPS, kamera movie, kamera photo, dan tripod

2. Kegiatan Studio, terdiri dari: Hardware: komputer dengan spesifikasi Prosesor diatas $2 \mathrm{Ghz}$, Memory $512 \mathrm{Mhz}$, Virtual Memory $128 \mathrm{Mhz}$, dan Hard Disk 80 Ghz. Software: video editor, photo editor, sound editor, animasi, dan video encoder.

3. Distribusi, terdiri dari: Hardware: CD Read/Write dan CD Blank \& casing, Software: Burning ROM

Peralatan dan perlengkapan standar yang disarankan tersebut di atas, dapat dikembangkan sesuai dengan kebutuhan-kemampuan serta sejalan dengan pengalaman masing-masing dalam pembuatan film dokumenter arkeologi.

\section{F. Proses Pembuatan Film Dokumenter Kearkeologian}

Proses produksi film dokumenter untuk arkeologi meliputi tiga jenis kegiatan, yaitu; kegiatan pra-lapangan, kegiatan lapangan dan kegiatan pasca-lapangan. Secara umum, ketiga jenis kegiatan tersebut dapat dijabarkan menjadi beberapa kegiatan yang lebih rinci, antara lain adalah (Riyanto, tt):

\section{- Kegiatan Pra Lapangan:}

1. Penentuan tema

2. Penyusunan skenario 
3. Pengumpulan bahan yang telah tersedia: foto, peta, video

4. Evaluasi kekurangan bahan

5. Penentuan lokasi hunting

6. Penentuan obyek / benda cagar budaya dan situs

7. Mempelajari karakter dan riwayat obyek / benda cagar budaya dan situs

8. Penyusunan POI (Point Of Interest): still image (foto, peta, gambar, denah) dan moving picture (animasi, video)

9. Mempersiapkan peralatan yang dibutuhkan: peta, GPS, kamera movie, kamera photo, tripod

10.Pembentukan tim: Tim Administrasi, Tim Eksekusi, Tim Pasca Eksekusi (manajemen data, editing, narasi, penggandaan)

11.Evaluasi persiapan dan uji peralatan

\section{- Kegiatan Lapangan:}

1. Pematangan susunan POI tiap sasaran, terdiri dari :

a. Narasumber (tokoh, ahili, pejabat)

b. Lingkungan (alam, sosial, budaya, ekonomi)

c. Interaksi publik dengan obyek/benda cagar budaya dan situs (aktivitas, perilaku, tanggapan, harapan)

d. Data arkeologi (bangunan, artefak, konteks, dan aspek lainnya)

e. Lain-lain: POI yang terekam tiba-tiba (snapshot dan candidshot)

2. Penyusunan jadwal eksekusi

3. Menghubungi narasumber (tokoh, ahli, pejabat)

4. Pelaksanaan eksekusi sesuai jadwal dan daftar POI, atur angel dan komposisi

5. Pencatatan seluruh hasil eksekusi

6. Merapikan seluruh bahan hasil eksekusi

7. Evaluasi seluruh hasil eksekusi

- Kegiatan Pasca Lapangan:

1. Evaluasi skenario, daftar POI, serta total bahan (bahan yang sudah tersedia ditambah dengan hasil eksekusi). Dokumen digital dari hasil penelitian arkeologi yang dapat dikembangkan untuk membuat film dokumenter arkeologi antara lain adalah: 


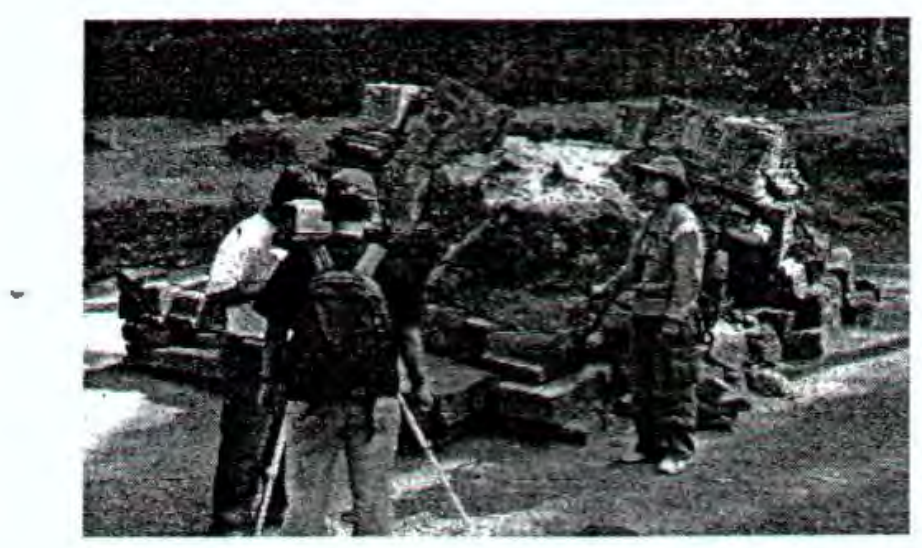

Suasana Ekselusi di Situs Arkeologi

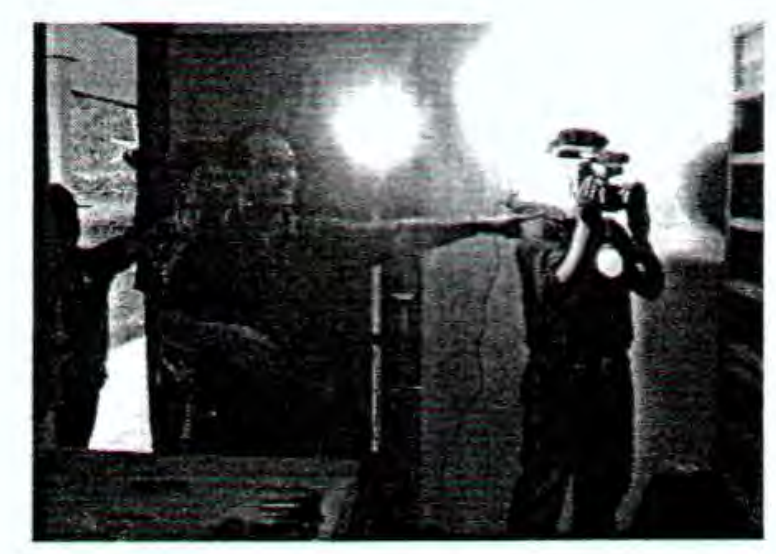

Eksekusi Tidak Harus Selalu di Luar Ruangan

a. Dokumen fotografi, antara lain dengan memanfaatkan fotografi digital dan digitasi melalui scanning negatif dan slide film

a. Dokumen video, antara lain melalui transfer dari hardcopy (VHS, Hi-8, atau Mini DV) ke dalam format digital (AVI, MPEG, dll) sehingga editable

b. Dokumen gambar, digitasi dilakukan melalui scanning

c. Dokumen peta (hasil) penelitian, digitasi dilakukan melalui scanning

2. Penyusunan time line sesuai skenario

3. Menyiapkan software: manajemen file, digitasi (scanning, transfer video), photo editor, animasi, video editor, sound editor, video encoder (AVI to MPEG), burning ROM

4. Pengujian masing-masing software

5. Penyiapan hardware: computer, $\mathrm{CD}$ writer, speaker, recorder

6. Pengujian masing-masing hardware 
7. Editing Awal, mengemas bahan hasil eksekusi menjadi bahan baku:

a. Foto: koreksi pencahayaan, warna dan penyesuaian dimensi pixel output (VCD, SVCD, DVD)

b. Video: pemilihan klip, toning klip

c. Animasi: penyesuaian durasi dan dimensi pixel

d. Peta: digitasi, penyesuaian kebutuhan dan dimensi pixel

e. Gambar: pilih sesuai dangan skenario dan penyesuaian dimensi pixel

8. EditingLanjutan:

a. Siapkan software video editor (misalnya Adobe Premier)

b. Tentukan total durasi (mencakup: opening, main, dan ending)

c. Setting Output (dimensi, fps, dan lainnya)

d. Pematangan Time Line

e. Penyiapan bahan: klip, musik, animasi, foto, peta, gambar

f. Penyusunan bahan sesuai dengan Time Line

9. Preview Project meliputi evaluasi, pematangan project dan narasi

10.Rendering Project: project to AVI (penentuan setting out put nya)

11.Encoding: AVI to MPEG

12.Burning: MPEG to VCD / SVCD / DVD

13.Uji produk

14.Pembuatan Master

15.Penggandaan

16.Labeling: lay out label (cakram dan casing), cetak label
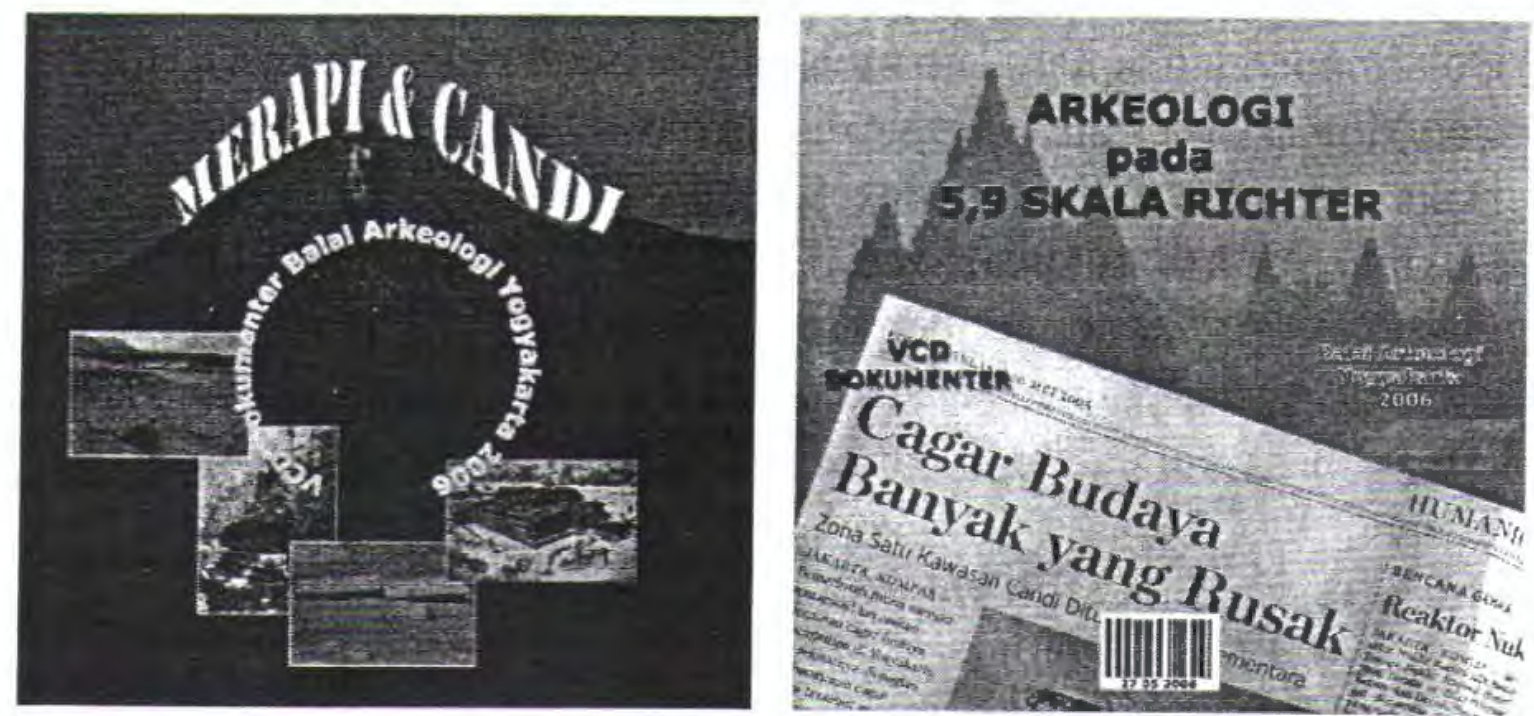

Video Dokumenter Kearkeologian Produksi Balai Arkeologi Yogyakarta 


\section{PENUTUP}

Sumberdaya arkeologi pada hakekatnya adalah milik masyarakat luas, sehingga segala sesuatu yang terjadi pada sumberdaya tersebut harus sepengetahuan masyarakat. Oleh karena' itu maka arkeolog secara profesional memiliki tanggungjawab untuk mempublikasikan hasil kegiatannya bukan hanya kepada kalangan akademik, tetapi juga kepada masyarakat luas. Dalam kaitannya dengan penelitian arkeologi, informasi yang dipublikasikan salah satunya mencakup hasil kegiatan penelitian dan intepretasi yang dihasilkan sumberdaya arkeologi yang bersangkutan. Oleh karena itu disadari bahwa penyebarluasan informasi hasil kegiatan arkeologi merupakan bagian yang tidak dapat dipisahkan dalam sebuah alur penelitian arkeologi.

Sehubungan dengan publikasi hasil kegiatan arkeologi, maka produk yang dipublikasikan kepada masyarakat luas adalah dokumentasi penelitian. Dokumen audio-visual sebagai salah satu bentuk dokumentasi penelitian, sampai saat ini belum banyak mendapat perhatian yang serius. Padahal sumber-sumber tersebut merupakan bahan yang sangat potensial untuk mempublikasikan arkeologi kepada masyarakat luas. Tulisan ini hanyalah semacam stimulan bagi yang belum tertarik, pemacu bagi yang sedang mencoba maupun tukar pikiran bagi yang telah bergelut pada bidang publikasi arkeologi melalui media audio-visual.

*Penulis mengucapkan terima kasih sebesar-besarnya kepada Drs. Sugeng Riyanto atas ide awal dan masukannya yang membangun pada tulisan ini.

\section{Catatan:}

1. Software Video Editor: Adobe Premier Pro / Premier Pro 2,

2. Software Photo Editor:Adobe Photoshop Creative Suite / Creative Suite $2 \&$ plugins

3. Software Sound Editor: Cool Edit, Jet Audio Extension

4. Software Animasi: Macromedia Flash, Macromedia Director, Macromedia Swish, Macromedia, Adobe Image Ready Creative Suite

5. Software Video Encoder: TMPGEnc 3.0 Express

6. Software Burning ROM: Nero 


\section{DAFTAR PUSTAKA}

Lemer, Shereen dan teresa Hoffman. "Bridging Archaeology to the Public: Programs to the Southwestern United States", dalam Francis P. McManamon dan Alf Hatton (ed.). Cultural Resources Management in Contemporary Society, Perspective on Management and Presenting the Past. London: Routtedge. Hlm: 231-246.

McGimsey, R. dan H.A. Davis (eds.). 1977. Management of Archaeological Resources: the Airlie House Report. Special Publication of the Society for American Archaeology.

Riyanto, Sugeng. Tidak terbit. Proses Produksi VCD Dokumenter Kearkeologian.

Riyanto, S. (2003). Pemasyarakatan Hasil Penelitian Arkeologi: Sebuah Kerangka. 'Berkala Arkeologi, 23(1), 132-145. https:/doi.org/10.30883/jba.v23i1.868

Sektiadi. 2000. "Perekaman Data Secara Piktorial Dalam Penelitian Arkeologi", dalam Panduan Dasar Penelirian Arkeologi. Yogyakarta: PTKA

Set, Sony dan Sita Sidharta. 2003. Menjadi Penulis Skenario Profesional. Jakarta: Grasindo.

Sharer, R.J. dan Wendy Ashmore. 2003. Archaeology, Discovering Our Past. New York: McGraw-Hill.

Tanudirjo, Daud Aris. 2003. "Benda Cagar Budaya, Milik Siapa?". Pengantar dalam Bambang Sulistyanto, Balung Buto, Warisan Budaya Dunia Dalam Perspekrif Masyarakat Sangiran. Yogyakarta: Penerbit Kunci ilmu. Hlm. xii-xxii. 